\title{
Analisis Faktor Penyebab Stres Kerja dan Dampaknya Pada Kinerja Karyawan Swasta Kota Samarinda di Masa Pandemi Covid-19
}

\author{
Asmadhini H. Rahmah ${ }^{1 *}$, Fitri Wardiani ${ }^{2}$ \\ 1,2Universitas Muhammadiyah Kalimantan Timur, Indonesia \\ 12ahr811@umkt.ac.id, 2fitriwardiani96@gmail.com \\ *Penulis korespondensi
}

\begin{abstract}
The emergence of Covid-19 in Indonesia has a significant impact on various aspects, especially human resources. The emergence of work stress due to changes in work patterns can result in decreased employee performance. Therefore, the aims of this study is to determine the influence of internal and external factors of employees on work stress as an intervening variable, as well as its impact on performance directly and indirectly. The subject of the study was a private employee of Samarinda City. Research data collection method is a survey method with questionnaires, while the analysis tool used is path analysis. The results of the study were that partially, workload, Job Insecurity and job satisfaction had a significant influence on work stress, however, the work environment and individual characteristics had no significant effect on work stress, but were simultaneously significant. While external factors, internal and work stress have a significant influence partially and simultaneously on employee performance. Direct influence is the best model of influence for this study.
\end{abstract}

Keywords: external factors, internal factors, work stress, employee performance, private employees

\begin{abstract}
Abstrak
Kehadiran Covid-19 di Indonesia memberikan dampak yang signifikan terhadap berbagai aspek, terutama Sumber Daya Manusia. Munculnya stress kerja akibat perubahan pola kerja dapat berakibat pada kinerja karyawan yang menurun. Oleh karena itu, tujuan penelitian ini untuk mengetahui pengaruh faktor internal dan eksternal karyawan terhadap stres kerja sebagai variabel intervening, serta dampaknya terhadap kinerja secara langsung dan tidak langsung. Subjek penelitian ini adalah karyawan swasta yang ada di Kota Samarinda. Metode pengumpulan data penelitian adalah metode survei dengan kuesioner, sedangkan alat analisis yang digunakan adalah analisis jalur. Hasil dari penelitian adalah secara parsial, beban kerja, Job Insecurity dan kepuasan kerja memiliki pengaruh yang signifikan terhadap stress kerja, namun, lingkungan kerja dan karakteristik individu tidak berpengaruh secara signifikan terhadap stress kerja, namun secara simultan signifikan. Sedangkan faktor eksternal, internal dan stress kerja memiliki pengaruh signifikan secara parsial dan simultan terhadap kinerja karyawan. Pengaruh langsung merupakan model pengaruh terbaik untuk penelitian ini.
\end{abstract}

Kata kunci: faktor eksternal, faktor internal, stres kerja, kinerja karyawan, karyawan swasta

\section{Cara Mengutip:}

Rahmah, A.H, \& Wardiani. F. (2021). Analisis Faktor Penyebab Stres Kerja dan Dampaknya pada Kinerja Karyawan Swasta Kota Samarinda di Masa Pandemi Covid-19. Esensi: Jurnal Bisnis dan Manajemen, 11(2), 225-236. https://doi.org/10.15408/ess.v11i2.22756. 


\section{PENDAHULUAN}

Pandemi Corona Virus Disease (Covid-19) adalah krisis kesehatan yang menjadi fokus seluruh dunia saat ini. Dimulai sejak awal tahun 2020, virus ini bermula dari otoritas kesehatan di kota Wuhan, Provinsi Hubei, Tiongkok yang mendeklarasikan ada 3 orang warganya yang tewas akibat virus itu tersebut, kemudian menyebar keseluruh pelosok dunia, termasuk Indonesia di bulan Maret 2020. Berdasarkan data dari situs resmi pemerintah untuk penanganan Covid -19, www.covid-19.go.id, hingga minggu terakhir di bulan April 2021, terkonfirmasi sebanyak 1. 647.138 orang terkonfirmasi terinfeksi virus Covid-19 di Indonesia. Hal tersebut membuat Indonesia memberlakukan kebijakan Pembatasan Sosial Berskala Besar (PSBB) untuk menekan penyebaran virus ini. Pembatasan ini pun berbuah himbauan pemerintah untuk bekerja dari rumah atau Work From Home (WFH) di seluruh Indonesia, termasuk Samarinda.

Samarinda sebagai ibukota Provinsi Kalimantan Timur, merupakan provinsi kelima terbesar kasus terkonfirmasi Covid-19 sebanyak 67.896 kasus (www.covid19.go.id). Menurut Gubernur Kalimantan Timur, H. Isran Noor yang dituliskan oleh Humasprov Kaltim (2021) di website resmi pemerintah Kalimantan Timur (www.kaltimprov.go.id) menyatakan bahwa dampak Covid-19 sangat luar biasa, terhadap kehidupan sosial dan ekonomi, belum lagi adanya pemutusan hubungan kerja (PHK) dan pekerja dirumahkan yang jumlahnya terus meningkat. Ini akan menyebabkan jumlah penduduk miskin baru akan bertambah. Pelaksana Tugas (PIt) Kepala Dinas Tenaga Kerja dan Transmigrasi (Disnakertrans) Provinsi Kaltim Datuk Badaruddin juga menjelaskan di website yang sama bahwa berdasarkan data yang diterima dari perusahaan per tanggal 7 April 2020, jumlah tenaga kerja yang dirumahkan 4.109 orang berasal dari 70 perusahaan di Kaltim. Sedangkan tenaga kerja mendapat Pemutusan Hubungan Kerja (PHK) 323 orang dari 33 perusahaan. Oleh karena itu, ancaman paparan virus Covid-19 dan PHK diduga akan sangat mempengaruhi mental masyarakat Samarinda terutama yang bekerja, sehingga stres kerja terbentuk.

Pemberlakuan Work From Home (WFH), menuntut karyawan merubah pola kerja mereka secara tiba-tiba, yang mengakibatkan karyawannya menjadi bingung karena tidak terbiasa dengan pola kerja yang seperti ini sehingga hal ini pun menimbulkan stres kerja. Untuk memperbaiki keadaan, sebaiknya stres kerja tidak diharapkan ada, karena jika stres kerja bermunculan, akan berdampak pada kinerja karyawan, yang pada akhirnya akan berdampak pada produktivitas perusahaan. Sedangkan dalam keadaan seperti ini, perusahaan sangat butuh peran karyawan yang bekerja dengan maksimal untuk dapat mempertahankan perusahaan yang juga sedang dalam keadaan terancam. Oleh karena itu, analisis terhadap faktor-faktor yang mempengaruhi stress kerja diharapkan dapat membantu untuk memulihkan kinerja karyawan.

Stress kerja yang terjadi pada seorang karyawan dapat disebabkan oleh dua faktor, yaitu faktor eksternal dan faktor internal. Faktor eksternal merupakan faktor yang meliputi faktor organisasional dan kondisi lingkungan kerja seperti lingkungan kerja dan beban kerja. Sedangkan faktor internal yang meliputi kondisi fisik dan psikologis dari karyawan seperti karakteristik individu, Job Insecurity dan kepuasan kerja (Smet, 1994). Lingkungan kerja yang berubah semenjak diberlakukan Work From Home mengakibatkan seorang karyawan dipaksa untuk beradaptasi dengan berbagai macam hal sehingga menimbulkan rasa tidak nyaman. Hanya karyawan yang dapat beradaptasi dengan baik lah yang dapat mengatasi 
ketidaknyamanan ini. Menurut Rizki (2016), Lingkungan kerja yang nyaman dan kondusif akan berpengaruh terhadap karyawan dalam melakukan pekerjaannya, yang berakibat akan menurunkan tingkat stres karyawan, sebaliknya apabila lingkungan kerja tidak kondusif dan tidak nyaman maka akan berdampak pada tingginya stres kerja karyawan.

Tidak berhenti sampai disitu, akibat paksaan untuk beradaptasi juga mengakibatkan seorang karyawan merasa beban kerjanya bertambah. Selain harus melaksanakan kewajiban yang biasa dilakukan, juga harus belajar beradaptasi dengan berbagai hal ditengah banyaknya ancaman yang timbul. Hal ini diperkuat oleh hasil penelitian Kusuma \& Soesatyo (2014) yang menyatakan bahwa beban kerja berpengaruh signifikan dan positif terhadap stres kerja, yang berarti jika beban kerja meningkat maka stress kerja pun akan meningkat.

Faktor internal seorang individu pun tidak kalah memberikan tekanan pada stress kerja yang berakibat menurunnya kinerja seorang karyawan. Karakteristik individu memiliki peranan penting dalam mengahadapi ancaman dan tekanan yang datangnya tiba-tiba dan penuh keterpaksaan ini. Berdasarkan penelitian Sulaimiah dkk. (2018) karakteristik individu memiliki pengaruh yang negatif terhadap stres kerja, sehingga jika semakin baik karakteristik seorang individu, maka akan semakin kecil tekanannya terhadap stres kerja. Beda halnya dengan Job Insecurity. Ketakutan seorang karyawan terhadap ancaman yang telah disebutkan mengakibatkan Job Insecurity semakin tinggi sehingga stress kerjanya pun akan semakin meningkat (Ibrahim dkk., 2020).

Timbulnya berbagai ketidaknyaman yang telah dijabarkan, berakibat juga terhadap menurunnya kepuasan kerja karena proses adaptasi akan menimbulkan hasil yang tidak maksimal pada setiap kegiatan. Kepuasan kerja sebagai salah satu faktor internal yang mempengaruhi stres kerja. Ripaldi dkk. (2016) menyatakan bahwa kepuasan kerja akan memperlihatkan respon seorang karyawan terhadap pekerjaan dalam beberapa aspek pekerjaannya, dimana aktivitas harian akan mempengaruhi tingkat kepuasan kerja.

Jika membandingkan faktor internal dan eksternal penyebab stres kerja pada seorang karyawan, maka dirasa cukup bagi kita untuk menarik kesimpulan bahwa faktor-faktor yang telah disebutkan tidak terlalu terasa bagi Pegawai Negeri Sipil (PNS), hal ini didukung oleh Peraturan Pemerintah (PP) tentang Manajemen Pegawai Negeri Sipil (PNS) yaitu PP Nomor 11 Tahun 2017 yang menyatakan bahwa "apabila terjadi perampingan organisasi atau kebijakan pemerintah yang mengakibatkan kelebihan PNS, maka PNS tersebut terlebih dahulu disalurkan pada instansi pemerintah lain. Apabila terdapat PNS yang bersangkutan tidak dapat disalurkan dan pada saat terjadi perampingan organisasi sudah mencapai usia 50 (lima puluh) tahun dan masa kerja 10 (sepuluh) tahun, maka dapat diberhentikan dengan hormat dengan mendapat hak kepegawaian sesuai dengan ketentuan peraturan perundang-undangan. Apabila PNS sebagaimana dimaksud: a. tidak dapat disalurkan pada instansi lain; b. belum mencapai usia 50 (lima puluh) tahun; dan c. masa kerja kurang dari 10 (sepuluh) tahun, menurut PP ini, diberikan uang tunggu paling lama 5 (lima) tahun. Apabila sampai dengan 5 (lima) tahun PNS sebagaimana dimaksud tidak dapat disalurkan, maka PNS tersebut diberhentikan dengan hormat dan diberikan hak kepegawaian sesuai dengan ketentuan peraturan perundang-undangan".

Berdasarkan peraturan tersebut, disimpulkan bahwa PNS memiliki posisi yang jauh lebih aman untuk merasakan dampak Work From Home yang berakibat pada stres kerja. 
Oleh karena itu, pada penelitian ini, hanya akan mengamati karyawan swasta sebagai subjek penelitian. Dengan demikian menarik untuk melakukan penelitian mengenai "Analisis Faktor Penyebab Stres Kerja dan Dampaknya pada Kinerja Karyawan Swasta Kota Samarinda di Masa Pandemi Covid-19".

\section{METODE}

Populasi dari penelitian ini yakni seluruh masyarakat di Samarinda yang memiliki pekerjaan sebagai karyawan swasta. Teknik sampling yang digunakan adalah Accidental Sampling. Jumlah sampel ditentukan dengan menggunakan rumus Lemeshow. Berdasarkan hasil perhitungan rumus Lemeshow, didapatkan jumlah sampel 385. Dalam penelitian ini sumber data yang didapat dengan menggunakan metode kuisioner yang disebarkan melalui Google Form.

Variabel dependen pada penelitian ini adalah Kinerja karyawan. Variabel independen terdapat 5 variabel, yaitu faktor eksternal (beban kerja dan lingkungan kerja), faktor internal (karakteristik individu, Job Insecurity dan kepuasan kerja). Sedangkan variabel interveningnya adalah stres kerja. Definisi operasional dari variabel-variabel penelitian adalah sebagai berikut:

a. Beban kerja adalah pekerjaan yang berlebih dari biasanya dan di luar kemampuan karyawan yang harus dikerjakan dalam jangka waktu tertentu. Indikator yang digunakan untuk mengukur variabel ini adalah pekerjaan yang berlebihan, waktu yang terdesak atau terbatas, sistem pengawasan yang tidak efisien, kurang tepatnya pemberian kewenangan sesuai dengan tanggung jawab yang diberikan (, Kurang umpan balik prestasi kerja, ketidakjelasan peran, perubahan-perubahan dalam pekerjaan, konflik antar pribadi dan antar kelompok dan seterusnya, frustrasi, dan perbedaan nilai-nilai perusahaan dengan nilai-nilai yang dimiliki pekerja.

b. Lingkungan kerja adalah tempat bagi para karyawan untuk menjalankan aktivitas dalam bekerja. Indikator yang digunakan untuk mengukur variabel ini adalah cahaya/ penerangan di tempat bekerja, suhu/temperatur udara di tempat bekerja, musik di tempat bekerja, sirkulasi di tempat bekerja, kebersihan di tempat bekerja dan keamanan di tempat bekerja.

c. Karakteristik individu adalah ciri-ciri dari seorang individu yang merupakan pembeda dengan individu lain. Indikator yang digunakan untuk mengukur variabel ini adalah minat, sikap terhadap diri sendiri, pekerjaan, dan situasi pekerjaan, kebutuhan individual, kemampuan dan kompetensi, pengetahuan tentang pekerjaan, serta emosi, suasana hati, perasaan keyakinan dan nilai-nilai.

d. Job Insecurity penilaian karyawan terhadap suatu keadaan dimana karyawan merasa terancam, tegang, gelisah, khawatir, stres, dan merasa tidak pasti dalam kaitannya dengan sifat dan keberadaan pekerjaan dimasa mendatang yang kemudian menimbulkan rasa tidak berdaya. Indikator yang digunakan untuk mengukur variabel ini adalah usia, gender, kepribadian, sosial ekonomi, tipe kontrak dan dukungan sosial.

e. Kepuasan kerja adalah adalah cara seorang karyawan mengekspresikan tentang pekerjaan yang di lakukan sehari-hari,atau bisa juga diartikan sebagai penilaian seseorang dalam 
melakukan pekerjaannya apakah seserorang tersebut sudah melakukan yang terbaik dalam pekerjaannya sehingga dia puas dengan hasil kerja yang di lakukan. Indikator yang digunakan untuk mengukur variabel ini adalah gaji, promosi, supervise, tunjangan tambahan, penghargaan, prosedur dan peraturan kerja, rekan kerja, pekerjaan itu sendiri, serta komunikasi.

f. Stres kerja adalah perasaan yang menekan atau merasa tertekan yang dialami karyawan dalam menghadapi pekerjaan. Indikator yang digunakan untuk mengukur variabel ini adalah beban kerja yang sulit dan berlebihan, tekanan dan sikap pemimpin yang kurang adil dan tidak wajar, konflik antara pribadi dan pimpinan atau kelompok kerja, balas jasa yang terlalu rendah, serta masalah keluarga.

g. Kinerja karyawan adalah tingkat keberhasilan seseorang secara keseluruhan selama periode tertentu dalam melaksanakan tugas dibandingkan dengan berbagai kemungkinan, seperti standar hasil kerja, target atau sasaran atau kriteria yang telah ditentukan terlebih dahulu telah disepakati bersama. Indikator yang digunakan untuk mengukur variabel ini adalah kualitas, kuantitas, efektivitas, ketepatan waktu, kemandirian dan komitmen kerja.

Analisis data yang digunakan dalam penelitian ini adalah analisis jalur (Path Analysis) Gambar 1 menunjukkan model diagram jalur berdasarkan paradigma hubungan antar variabel.

\section{Gambar 1. Model Diagram Jalur}

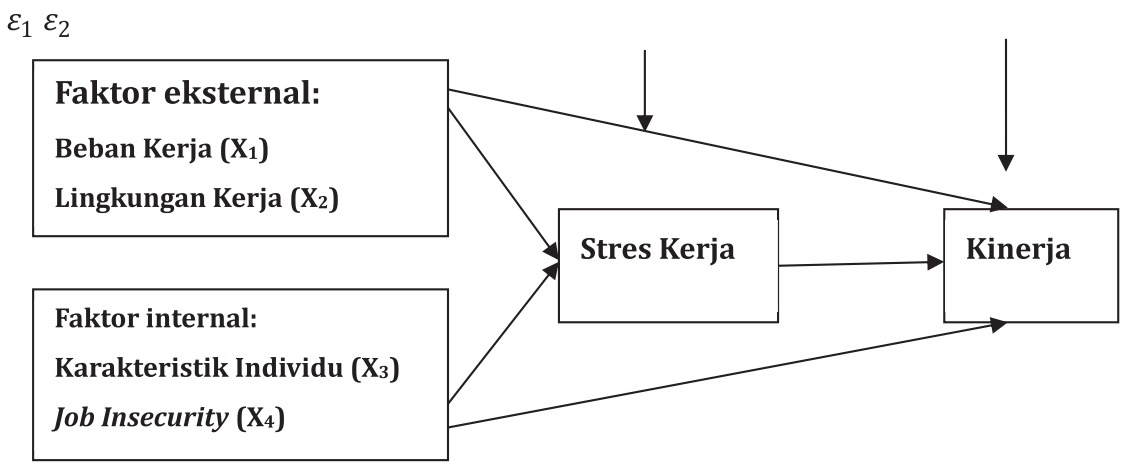

\section{HASIL DAN PEMBAHASAN}

Sebelum melakukan pengujian dengan menggunakan analisis jalur, maka langkah pertama adalah melakukan uji asumsi. Pengujian normalitas dengan menggunakan uji One-Sample Kolmogorov-Smirnov Test membuktikan bahwa kedua tahap uji normal. Uji heteroskedastisitas dilakukan dengan mendeteksi ada tidaknya gejala penyimpangan varians dengan memperhatikan sebaran data pada scatterplot. Berdasarkan gambar scatterplot yang tampil pada pengujian, kedua tahap pun tidak memiliki pola tertentu atau acak maka diduga tidak ada heteroskedastisitas. Jadi. analisis jalur tahap 1 dan 2 mengandung model yang homoskedastisitas. Kemudian, uji multikolinearitas yang dilakukan dengan menguji nilai Variance Inflation Factor (VIF) lebih kecil dari 10 maka disimpulkan seluruh variabel pada kedua tahap analisis jalur tidak ada multikolinearitas. 
Tabel 1. Uji t Analisis Jalur Tahap 1

\begin{tabular}{ccccc}
\hline Variabel & Beta & P - Value & Tingkat Signifikansi & Keterangan \\
\hline Beban Kerja & 0,450 & 0,000 & 0.05 & Signifikan \\
Lingkungan Kerja & 0,22 & 0,620 & 0.05 & Tidak signifikan \\
Karakteristik Individu & $-0,064$ & 0,122 & 0.05 & Tidak signifikan \\
Job Insecurity & 0,117 & 0,002 & 0.05 & Signifikan \\
Kepuasan Kerja & $-0,299$ & 0,000 & 0.05 & Signifikan \\
P-value (Uji F) & 0,000 & & & \\
Koefisien Determinasi & 0,436 & & & \\
\hline
\end{tabular}

Sumber: Data Primer (Diolah. 2021)

Dilihat dari Tabel 1. diatas nilai $\mathrm{R}^{2}$ sebesar 0.436 atau 43,6 \%. artinya secara serentak variabel independent (beban kerja, lingkungan kerja, karakteristik individu, Job Insecurity dan kepuasan kerja) mempunyai pengaruh sebesar 43,6 \% terhadap variabel intervening (stres kerja). Sedangkan 56,4 \% sisanya dipengaruhi oleh variabel lain diluar variabel independent (beban kerja, lingkungan kerja, karakteristik individu, Job Insecurity dan kepuasan kerja). Kemudian pada Tabel 1. diatas dilihat p-value lebih kecil dari tingkat signifikansi $0.000<$ 0.05). Maka $\mathrm{H}_{0}$ ditolak yang berarti ada pengaruh yang signifikan antara variabel independent (beban kerja, lingkungan kerja, karakteristik individu, Job Insecurity dan kepuasan kerja) terhadap variabel intervening (stres kerja) secara bersama-sama.

Untuk melihat bagaimana pengaruh variabel independent (beban kerja, lingkungan kerja, karakteristik individu, Job Insecurity dan kepuasan kerja) terhadap variabel intervening (stres kerja) secara parsial digunakan uji t. sedangkan untuk melihat besarnya pengaruh masing-masing variabel independent (beban kerja, lingkungan kerja, karakteristik individu, Job Insecurity dan kepuasan kerja) terhadap variabel intervening (stres kerja) digunakan angka Standardized Coefficient atau Beta. Berdasarakan Tabel 1. Diketahui bahwa beban kerja, Job Insecurity dan kepuasan kerja memiliki pengaruh terhadap stress kerja, karena nilai p-valuenya < dari 0,05, sedangkan lingkungan kerja dan karakteristik individu tidak memiliki pengaruh yang signifikan.

Untuk melihat besarnya pengaruh variabel independent (beban kerja, lingkungan kerja, karakteristik individu, Job Insecurity dan kepuasan kerja) terhadap variabel intervening (stres kerja) digunakan angka Standardized Coefficient atau Beta. Tabel 1 memperlihatkan bahwa nilai beta pada variabel beban kerja (0.450) lebih besar dari nilai beta pada variabel lainnya. Berarti pada model ini beban kerja paling besar pengaruhnya terhadap stress kerja dibandingkan variabel lainnya.

Tabel 2 menunjukkan nilai $\mathrm{R}^{2}$ sebesar 0.446 atau $44.6 \%$. artinya secara variabel independent (beban kerja, lingkungan kerja, karakteristik individu, Job Insecurity, kepuasan kerja) dan variabel intervening (stres kerja) mempunyai pengaruh sebesar $44.6 \%$ terhadap variabel dependent (kinerja karyawan). Sedangkan $55.4 \%$ sisanya dipengaruhi oleh variabel lain diluar variabel independent (beban kerja, lingkungan kerja, karakteristik individu, Job Insecurity, kepuasan kerja) dan variabel intervening (stres kerja). 
Tabel 2. Uji t Analisis Jalur Tahap 2

\begin{tabular}{|c|c|c|c|c|}
\hline Variabel & Beta & P - Value & $\begin{array}{c}\text { Tingkat } \\
\text { Signifikansi }\end{array}$ & Keterangan \\
\hline Beban Kerja & 0.175 & 0.000 & 0.05 & signifikan \\
\hline Lingkungan Kerja & 0.169 & 0.000 & 0.05 & signifikan \\
\hline Karakteristik Individu & 0.344 & 0.000 & 0.05 & signifikan \\
\hline Job Insecurity & 0.128 & 0.001 & 0.05 & signifikan \\
\hline Kepuasan Kerja & 0.247 & 0.000 & 0.05 & signifikan \\
\hline Stres kerja & -0.112 & 0.012 & 0.05 & signifikan \\
\hline P-value (Uji F) & 0,000 & & & \\
\hline Koefisien Determinasi & 0,446 & & & \\
\hline
\end{tabular}

Sumber: Data Primer (Diolah. 2021)

Pada tabel 2. Uji F dilihat berdasarkan p-value lebih kecil dari tingkat signifikansi $(0.000<0.05)$. Maka $\mathrm{H}_{0}$ ditolak yang berarti ada pengaruh yang signifikan antara variabel independent (beban kerja, lingkungan kerja, karakteristik individu, Job Insecurity, kepuasan kerja) dan variabel intervening (stres kerja) terhadap variabel dependent (kinerja karyawan) secara bersama-sama.

Untuk melihat bagaimana pengaruh variabel independent (beban kerja, lingkungan kerja, karakteristik individu, Job Insecurity, kepuasan kerja) dan variabel intervening (stres kerja) terhadap variabel dependent (kinerja karyawan) secara parsial digunakan uji t. sedangkan untuk melihat besarnya pengaruh masing-masing variabel digunakan angka Standardized Coefficient atau Beta. Untuk melihat besarnya pengaruh pengaruh variabel independent (beban kerja, lingkungan kerja, karakteristik individu, Job Insecurity, kepuasan kerja) dan variabel intervening (stres kerja) terhadap variabel dependent (kinerja karyawan) digunakan angka Standardized Coefficient atau Beta. Tabel 2 menunjukkan nilai beta pada variabel stress kerja (0.012) lebih besar dari nilai beta pada variabel lainnya. Berarti pada model ini stress kerja paling besar pengaruhnya terhadap kinerja karyawan dibandingkan variabel lainnya. Untuk menghitung pengaruh langsung atau Direct Effect. digunakan formula sebagai berikut:

- Pengaruh variabel beban kerja terhadap stress kerja:

- Pengaruh variabel lingkungan kerja terhadap stress kerja

- Pengaruh variabel karakteristik individu terhadap stress kerja

- Pengaruh variabel Job Insecurity terhadap stress kerja

- Pengaruh variabel kepuasan kerja terhadap stress kerja

- Pengaruh variabel beban kerja terhadap kinerja karyawan

- Pengaruh variabel lingkungan kerja terhadap kinerja karyawan

- Pengaruh variabel karakteristik individu terhadap kinerja karyawan

- Pengaruh variabel Job Insecurity terhadap kinerja karyawan

- Pengaruh variabel kepuasan kerja terhadap kinerja karyawan

- Pengaruh variabel stress kerja terhadap kinerja karyawan

$$
\begin{aligned}
& X_{1} \rightarrow Z=0.450 \\
& X_{2} \rightarrow Z=0.022 \\
& X_{3} \rightarrow Z=-0.064 \\
& X_{4} \rightarrow Z=0.117 \\
& X_{5} \rightarrow Z=-0.299 \\
& X_{1} \rightarrow Y=0.175 \\
& X_{2} \rightarrow Y=0.169 \\
& X_{3} \rightarrow Y=0.344 \\
& X_{4} \rightarrow Y=0.128 \\
& X_{5} \rightarrow Y=0.247 \\
& Z \rightarrow Y=-0.112
\end{aligned}
$$


Berdasarkan hasil dari pengaruh langsung diatas, didapatkan bahwa beban kerja paling besar pengaruhnya terhadap stress kerja dibandingkan dengan pengaruh langsung yang lain dengan nilai 0,450. Kemudian diikuti oleh pengaruh karakteristik individu terhadap kinerja sebesar 0.344. kedua hal ini dapat dijadikan perhatian besar oleh para pemilik perusahaan swasta dimasa pandemi Covid-19 ini, dikarenakan beban kerja paling berpengaruh terhadap stress kerja, dan karakteristik individunya pun memiliki pengaruh paling besar terhadap kinerja.

Untuk menghitung pengaruh tidak langsung atau Indirect Effect. digunakan formula sebagai berikut:

Pengaruh variabel beban kerja terhadap kinerja karyawan melalui stress kerja

$\mathrm{X}^{1} \rightarrow \mathrm{Z} \rightarrow \mathrm{Y}=0.450 \mathrm{x}-0.112=-0.0504$

Pengaruh variabel lingkungan kerja terhadap kinerja karyawan melalui stress kerja

$\mathrm{X}_{2} \rightarrow \mathrm{Z} \rightarrow \mathrm{Y}=0.022 \times-0.112=-0.002464$

Pengaruh variabel karakteristik individu terhadap kinerja karyawan melalui stress kerja

$\mathrm{X}_{3} \rightarrow \mathrm{Z} \rightarrow \mathrm{Y}=-0.064 \mathrm{x}-0.112=0.007168$

Pengaruh variabel Job Insecurity terhadap kinerja karyawan melalui stress kerja

$\mathrm{X}_{4} \rightarrow \mathrm{Z} \rightarrow \mathrm{Y}=0.117 \mathrm{x}-0.112=-0.013104$

Pengaruh variabel kepuasan kerja terhadap Dalam pengaruh tidak langsung pun variabel beban kerja terhadap kinerja karyawan melalui stress kerja. Hal ini disimpulkan melalui besaran nilai tanpa memperhatikan nilai negatif dan posistifnya, karena nilai negatif dan positif hanya merupakan arah hubungan saja. Dilihat dari nilainya. maka disimpulkan bahwa pengaruh langsung lebih besar nilainya daripada pengaruh tidak langsung. Sehingga untuk menaikkan sebuah kinerja, tidak perlu harus melalui mengelola stress kerja terlebih dahulu. Hal ini dapat diatasi secara langsung, jika ingin mengatasi kinerja, langsung dengan mengatasi penyebab turunnya kinerja saja.

Dari hasil penghitungan koefisien determinasi pada model analisis jalur tahap pertama didapatkan nilai sebesar 0.436 atau $43.6 \%$. Dari nilai tersebut dapat diartikan bahwa pengaruh faktor eksternal dan faktor internal terhadap stress kerja hanya sebesar $43.6 \%$. sedangkan $56.4 \%$ sisanya dipengaruhi oleh variabel lain yang tidak masuk dalam penelitian ini. Jika dilihat dari besaran koefisien determinasi. memang memiliki pengaruh yang termasuk kecil terhadap stress kerja. Hal ini disebabkan oleh banyaknya hal yang mempengaruhi stress kerja. Tidak hanya oleh faktor eksternal dan internal yang digunakan pada penelitian ini, tetapi banyak faktor lain.

Berdasarkan hasil dari uji $\mathrm{F}$, seluruh faktor ini mempengaruhi stress kerja dengan baik secara bersama-sama, namun jika dilihat berdasarkan uji t, faktor eksternal berupa lingkungan kerja dan faktor internal berupa karakteristik individu tidak secara signifikan mempengaruhi stress kerja. Lingkungan kerja dalam bentuk cahaya penerangan di tempat bekerja, suhu, musik ditempat kerja, sirkulasi, kebersihan dan keamanan tidak memiliki pengaruh yang signifikan terhadap stress kerja di masa pandemi. Hal ini diduga karena karyawan swasta tidak terlalu fokus pada lingkungan kerjanya lagi, mereka terlalu fokus dengan proses adaptasi dan rasa khawatir berupa Job Insecurity yang mereka rasakan. Ditambah lagi, sebagian besar karyawan swasta mengalami WFH (Work From Home). 
Begitu juga karakteristik individu, di masa pandemi ini, semua oarng memiliki rasa khawatir yang sama tingginya, sehingga, karakteristik seseorang sebagai individu tidak lagi mempengaruhi mereka dalam mengelola stress kerja, mugkin jika keadaan nya normal bukan pada pandemi, karakteristik individu dapat memiiki pegaruh yang signifikan. Minat, sikap terhadap diri sendiri, kebutuhan individu, pengetahuan tentang pekerjaan dan suasana hati serta keyakinan, tidak lagi menjadi tonggak utama munculnya stress pada seseorang.

Beban kerja tentu memiliki pengaruh yang besar terhadap stress kerja, hal ini dapat dilihat melalui nilai pada perhitungan pengaruh langsung, dari perhitungan tersebut, beban kerja memiliki nilai tertinggi diantara yang lainnya. Hal ini sejalan dengan penelitian yang dilakukan oleh Kusuma \& Soesatyo (2014), beban kerja memiliki pengaruh yang signifikan dan positif terhadap stress kerja. Beban kerja yang berbeda ketika pandemi ini menambah peningkatan stress kerja pada karyawan swasta di amarinda, hal ini di karenakan makin beratnya pekerjaan yang beubah sistem kerjanya menyesuaikan dengan kedaan. Oleh karena itu karyawan dituntut untuk dapat mengikuti pekerjaan dengan sistem baru namun juga dituntut menyelesaikannya seperti biasa, adaptasi yang menjadi persoalan disini. Sehingga beban kerja memiliki pengaruh yang besar pada peningkatan stress kerja.

Tidak hanya beban kerja, sejalan dengan pemikiran Ibrahim dkk. (2020), Job Insecurity memiliki pengaruh positif dan signifikan terhadap stress kerja. Hamper sama dengan beban kerja, namun Job Insecurity adaah kekhawatiran yang muncul dari diri karyawan tersebut, rasa tidak aman yang dirasakan pada saat pandemic ini, bukan hanya tidak aman terhadap penularan Covid-19 yang mengancam, namun ada hal lebih menakutkan lagi, yaitu ancaman pengurangan karyawan, sehingga membuat mereka merasa takut. Rasa yang tidak menentu ini dikarenakan mereka sebagai pekerja swasta yang bisa saja sewaktu-waktu mengurangi jumlah pegawai sesuai kemampuan mereka saat itu.

Kepuasan kerja pun ternyata memiliki dampak yang signifikan namun negatif terhadap stress kerja, maka jika kepuasan kerja meningkat, maka stress kerja akan menurun. Sejalan dengan hasil penelitian Ripaldi dkk. (2016). Kepuasan merupakan terpenuhinya kebutuhan dan keinginan karyawan swasta terhadap apa yang mereka inginkan saat bekerja. Apabila keinginan dan kebutuhan seseorang telah terpenuhi dan terpuaskan, maka walaupun di masa pandemi, stress kerja mereka tidak akan meningkat, justru akan meningkatkan kinerja mereka.

Berdasarkan hasil penghitungan koefisien determinasi pada model analisis jalur tahap kedua didapatkan nilai sebesar 0.446 atau $44.6 \%$. Nilai tersebut dapat diartikan bahwa pengaruh faktor eksternal, faktor internal dan stress kerja terhadap kinerja karyawan hanya sebesar $44.6 \%$. sedangkan $55.4 \%$ sisanya dipengaruhi oleh variabel lain yang tidak masuk dalam penelitian ini. Jika dilihat dari besaran koefisien determinasi. memang memiliki pengaruh yang termasuk kecil terhadap kinerja karyawan. Hal ini disebabkan oleh banyaknya hal yang mempengaruhi kinerja karyawan swasta di Samarinda. Tidak hanya oleh faktor eksternal, internal dan stress kerja yang digunakan pada penelitian ini, tetapi banyak faktor lain.

Berdasarkan hasil dari uji F, seluruh faktor ini mempengaruhi kinerja karyawan dengan baik secara bersama-sama. Namun, uji t pada tahap 2 ini lebih baik, karena seluruh faktor dan stress kerja memiliki pengaruh yang signifikan terhadap kinerja karyawan swasta di Samarinda. Beban kerja salah satunya merupakan pekerjaan yang berlebihan, waktu yang 
terbatas, system pengawasan yang tidak efisien, dan lain-lain seperti sudah dijelaskan pada Bab II. Berdasarkan pemahaman pada apa itu beban kerja, maka tentunya pada saat pandemi seperti ini, beban kerja akan sangat mempengaruhi kinerja seorang karyawan. Pekerjaan yang berlebihan memberikan tambahan beban bagi karyawan karena telah ada beban untuk beradaptasi dengan sistem kerja yang baru dan juga rasa takut tertular penyakit di masa pandemi ini. Menurut penelitian Rizka dkk. (2020), pekerjaan yang sudah berlebihan akan berpengaruh pada kondisi fisik dan emosional karyawan sehingga merubah kebiasaan dan kinerjanya seperti kelambatan dalam bekerja, kesulitan bekerja sama.

Tujuan utama dalam melakukan pengaturan lingkungan kerja yakni agar menghasilkan produktivitas pada perusahaan. Ketika lingkungan kerja kondusif, maka akan menghasilkan dampak yang positif bagi kinerja karyawannya. Lingkungan kerja seperti yang dijabarkan oleh Sembiring (2020) adalah cahaya di tempat bekerja, suhu udara, musik, sirkulasi udara, kebersihan dan keamanan. Oleh karena itu, dalam penelitian ini, lingkungan kerja berpengaruh signifikan pada kinerja karyawan.

Karakteristik individu pun memiliki pengaruh yang signifikan terhadap kinerja karyawan. Hal ini diduga karena apabila seseorang memang memiliki minat, sikap, kebutuhan individu, kemampuan, kompetensi, pengetahuan tentang pekerjaan yang baik dan emosi yang dapat terkendali di masa pandemi seperti ini, maka mereka akan bisa tetap mempertahankan kinerjanya. Karyawan swasta di samarinda pada saat masa pandemi ini, diduga memiliki sebagian besar dari indikator yang telah disebutkan tersebut, sehingga hasil dari penelitian ini menyatakan bahwa karakteristik individu memiliki pengaruh yang signifikan terhadap kinerja karyawan. Hal ini didukung oleh penelitian yang dituliskan oleh Adam \& Nurdin, (2019).

Robbins (2006) menyebutkan ada enam indikator untuk mengukur kinerja karyawan yaitu kualitas, kuantitas, ketepatan waktu, efektivitas, kemandirian dan komitmen kerja. Dimana hasil yang didapatkan dalam penelitian ini membuktikan bahwa apabila Job Insecurity pada karyawan meningkat dan membuat karyawan menjadi stres, hal ini akan berpengaruh kepada kemandiran karyawan tersebut karena tidak merasa mendapatkan dukungan dari atasan ataupun teman kerja dan karyawan merasa insecure sehinggan tidak dapat mengerjakan perkejaannya dengan mandiri dan ini tentu saja akan mengurangi penilaian dari kinerja mereka.

Pada kepuasan kerja, dimana hasil yang didapatkan dalam penelitian ini membuktikan bahwa apabila kepuasan kerja karyawan menurun dan membuat karyawan menjadi stres, hal ini akan berpengaruh kepada tidak adanya komitmen kerja yang dipegang oleh karyawan tersebut dan tentu saja ini akan mengurangi penilaian kinerja. Kepuasan kerja menurut Spector (2013) memiliki sembilan aspek, yaitu, gaji, promosi, hubungan dengan atasan, tunjangan tambahan, penghargaan, prosedur kerja, rekan kerja, pekerjaan itu sendiri dan komunikasi. Tentunya kesembilan aspek tersebut akan sangat berpengaruh kepada kinerja seorang karyawan apabila dikurangi, apalagi dimasa pandemi seperti ini bagi seorang karyawan swasta di Samarinda. Gaji saja apabila berkurang sedikit, dapat menyebbakan protes dari karyawan, yang tentunya akan membuat karyawan menguragi bekerja, atau bahkan tidak mau bekerja sama sekai, dan ini berhubungan juga dengan Job Insecurity yang akhirnya muncul pada karyawan. 
Stress dapat disebabkan oleh beberapa hal yaitu beban kerja yang sulit dan berlebihan, sikap yang kurang adil, waktu dan peralatan yang tidak memadai, konflik antara teman kerja, balas jasa yang terlalu rendah dan masalah keluarga (Hasibuan, 2012). Tentunya keenam hal tersebut sangat mempengaruhi kinerja karyawan jika dirasakan salah satu saja. Apabilan beban kerja menjadi lebih sulit dan berlebihan di masa pandemic ini, karena perubahan sistem kerja dan terpaksa harus beradaptasi, dan karena bekerja dirumah maka terkadang jam kerja menjadi tidak menentu, hal ini dapat menyebabkan stress bagi karyawan yang menyebabkan kinerja mereka pun juga akan turun. Pada penelitian Prasad dkk (2020), Wahyunanti dkk (2018), dan Ahmed \& Ramzan (2013) menyatakan hal yang sama, bahwa stress kerja akan sangat berpengaruh pada kinerja karyawan, apabila stress kerja meningkat, maka kinerja karyawan akan ikut menurun.

Dilihat dari hasilnya diatas diketahui bahwa pengaruh langsung (faktor eksternal, internal dan stress kerja terhadap kinerja karyawan) memiliki pengaruh yang lebih besar daripada pengaruh tidak langsung (faktor eksternal dan faktor internal terhadap kinerja karyawan melalui stress kerja). Hal ini juga dapat dibuktikan melalui analisis pengaruh total yang telah dilakukan bahwa pengaruh langsung nilai betanya lebih besar daripada pengaruh langsung. Hal ini membuktikan, bahwa untuk menangani kinerja karyawan yang menurun, tidak perlu dengan memperbaiki stress kerja terlebih dahulu. Manajemen dapat langsung mengatasinya dengan memperbaiki faktor-faktor yang mempengaruhi kinerja. Karena secara otomatis jika faktor-gaktor tersebut diperbaiki, maka stress kerja menurun, ditandai dengan kinerja karyawan yang baik.

\section{SIMPULAN}

Secara parsial, beban kerja, Job Insecurity dan kepuasan kerja memiliki pengaruh yang signifikan terhadap stress kerja, namun, lingkungan kerja dan karakteristik individu tidak berpengearuh secara signifikan terhadap stress kerja. Secara simultan, faktor eksternal (beban kerja dan lingkungan kerja) dan faktor internal (karakteristik individu, Job Insecurity dan kepuasan kerja) berpengaruh secara signifikan terhadap stres kerja. Faktor eksternal (beban kerja dan lingkungan kerja), faktor internal (karakteristik individu, Job Insecurity dan kepuasan kerja) dan stress kerja berpengaruh signifikan secara parsial terhadap kinerja. Secara simultan, Faktor eksternal (beban kerja dan lingkungan kerja), faktor internal (karakteristik individu, Job Insecurity dan kepuasan kerja) dan stress kerja berpengaruh secara signifikan terhadap kinerja. Pengaruh langsung merupakan model paling baik pada penelitian ini, sehingga untuk memperbaiki kinerja, tidak harus melalui stress kerja terlebih dahulu.

\section{PUSTAKA ACUAN}

Adam, I. M., \& Nurdin, R. (2019). The Influence of Individual Characteristics, Organizational Characteristics and Work Environment on Employee Performance and Its Impact on the Performance of Bkkbn Representative Organization of Aceh Province. International Journal of Business and Social Science, 10(5), 95-107. https://doi.org/10.30845/ijbss. v10n5p10 
Ahmed, A., \& Ramzan, M. (2013). Effects of Job Stress on Employees Job Performance A Study on Banking Sector of Pakistan. IOSR Journal of Business and Management, 11(6), 61-68. https://doi.org/10.9790/487x-1166168.

Hasibuan, M. (2012) Manajemen Sumber Daya Manusia. Edisi Revisi. Jakarta: Bumi Aksara. Ibrahim, I. D. K., Sidharta, R. B. F. I., \& Rodhi, M. N. (2020). Hubungan Antara Job Insecurity Terhadap Stres Karyawan Pelaku Pariwisata Perhotelan Akibat Dampak Pandemi Covid-19 (Studi Pada Karyawan Golden Palace Hotel Lombok). Jurnal Manajemen Dan Keuangan, 9(2), 223-237. https://doi.org/10.33059/jmk.v9i2.2627

Kusuma, A. A., \& Soesatyo, Y. (2014). Pengaruh Beban Kerja Terhadap Stres Kerja dan Dampaknya Terhadap Kinerja Karyawan. Jurnal Ilmu Manajamen, 2(2), 375-386.

Prasad, K., Vaidya, R. W., \& Mangipudi, M. R. (2020). Effect of Occupational Stress and Remote Working on Psychological Well-being of Employees: An Empirical Analysis During Covid-19 Pandemic Concerning Information Technology Industry in Hyderabad. Indian Journal of Commerce \& Management Studies, 6(2), 1-13. https://doi.org/10.18843/ ijcms/v11i2/01

Ripaldi, A., Marnis, M., \& Restu, R. (2016). Pengaruh Kepuasan Kerja dan Organizational Citizenship Behavior Terhadap Stres Kerja Dan Retensi Karyawan di PT Multi Auto Intrawahana Pekanbaru. Jurnal Online Mahasiswa Fakultas Ekonomi Universitas Riau, 4(1), 518-532.

Rizka, F. M., Ardiana, I. D. K. R., \& Andjarwati, T. (2020). The Effect of Workload, Pay Satisfaction , Work Satisfaction on Turnover Intention and Performance of Employees of Angkasa Pura Logistic Indonesia. International Journal of Social Science and Economics Invention, 6(2), 234-241.

Rizki, M. dkk. (2016). Pengaruh Lingkungan Kerja Terhadap Stres Kerja Karyawan (Studi Pada Karyawan PT PLN (Persero) Distribusi Jawa Timur Area Pelayanan Malang). Jurnal Administrasi Bisnis (JAB), 35(2), 54-59.

Robbins, S. P. (2006). Perilaku Organisasi. Edisi Kesepuluh. Jakarta: Gramedia.

Sembiring, H. (2020). Pengaruh Motivasi dan Lingkungan Kerja Terhadap Kinerja Karyawan pada Bank Sinarmas Medan. Jurnal Akuntansi Dan Manajemen, 13(1), 10-23.

Smet, B. (1994). Psikologi Kesehatan. Jakarta; PT. Grasindo

Spector, P. E. (2013). Industrial and Organizational Psychology. Canada: John Wiley and Son Inc.

Sulaimiah, S., Nururly, S., Suprayetno, J., \& Nasir, M. (2018). Pengaruh Karakteristik Individu, Karakteristik Pekerjaan, Lingkungan Kerja Terhadap Stres Kerja Karyawan Administarsi Umum Rumah Sakit Umum Daerah Provinsi NTB. Distribusi - Journal of Management and Business, 6(1), 47-54. https://doi.org/10.29303/jdm.v6i1.19

Wahyunanti, T., Ardiana, D. K. R., \& Ridwan, M. S. (2018). The Effect of Individual Characteristics, Employees Commitment, Job Stress on Job Satisfaction and Employees Performance in PT. Timbul Persada in Turban East Java. The International Symposium Proceeding 2018, 103-107. 